\title{
Fe de erratas / Erratum
}

P. J. Cordero, P. Cordero \& J. Ortego. 2016. New field data for old museum specimens: A peculiar cricket (Grylloidea, Orthoptera) from SW Spain. Graellsia, 72(1): e045. http://dx.doi.org/10.3989/graellsia.2016.v72.160

En las páginas 1 y 2 se han utilizado por error las denominaciones Thilptoblemus y Thliptoblemus para referirse al subgénero de Sciobia cuya grafía correcta es Thliptoblemmus Saussure, 1898. I On pages 1 and 2 have been used mistakenly Thilptoblemus and Thliptoblemus names to refer to the subgenus of Sciobia whose correct spelling is Thliptoblemmus Saussure, 1898.

19 de octubre de 2016 


\title{
NEW FIELD DATA FOR OLD MUSEUM SPECIMENS: A PECULIAR CRICKET (GRYLLOIDEA, ORTHOPTERA) FROM SW SPAIN
}

\author{
Pedro J. Cordero ${ }^{1 *}$, Pau Cordero ${ }^{2} \&$ Joaquín Ortego $^{3}$ \\ ${ }^{1}$ Grupo de Investigación de la Diversidad Genética y Cultural, Instituto de investigación en \\ Recursos Cinegéticos, IREC (CSIC-UCLM-JCCM), Ciudad Real, Spain \\ ${ }^{2}$ Measuring All Sound Studio (MASS), Mataró, Spain \\ ${ }^{3}$ Departamento de Ecología Integrativa, Estación Biológica de Doñana (EBD-CSIC), Seville, Spain \\ *Author for correspondence: pedrojavier.cordero@uclm.es
}

\begin{abstract}
We obtained the first records of Sciobia (Thilptoblemus) natalia in Europe after a single record from Algeciras (Spain), about one century ago. We found the species in Tarifa, Benelup-Casas Viejas and Alcalá de los Gazules (Cádiz province) in plots with open land and herbaceous vegetation of wasteland, cattle states, edges of agricultural land, and hedgerows of pathways and local roads. The species may be common locally, in late spring. It may coexist with Sciobia (Thliptoblemus) caliendrum although the later presents a wider ecological spectrum whereas $S$. ( $T$. ) natalia prefers dense vegetation in more humid soils. Acoustic analyses indicate that the song of both species are very different, making field identification feasible. S. (T.) natalia may however easily go unnoticed among populations of the more conspicuous $S$. (T.) caliendrum. We discuss possible reasons why this species has gone unnoticed so far and factors that may pose at risk the maintenance of its populations.
\end{abstract}

Key words: Sciobia natalia; S. caliendrum; Coexistence; European distribution; Oscilogram; Sonogram.

\section{RESUMEN}

Nuevos datos de campo para viejos especímenes de museo: Un grillo (Grylloidea, Orthoptera) peculiar del SO-España

Obtenemos las primeras observaciones of Sciobia (Thilptoblemus) natalia en Europa después de un único registro de Algeciras hace casi un siglo. Hemos encontrado la especie en Tarifa, Benalup-Casas Viejas y Alcalá de los Gazules (provincia de Cádiz) en terrenos abiertos con vegetación herbácea de baldíos, fincas ganaderas y bordes de parcelas agrícolas, caminos y carreteras. Puede ser localmente común a finales de primavera y coexistir con Sciobia (Thliptoblemus) caliendrum, especie de más amplio espectro ecológico mientras que $S$. (T.) natalia muestra preferencia por vegetación más densa en suelos más húmedos. El análisis del canto de ambas especies muestra notables diferencias y su identificación en el campo es posible, aunque $S$. (T.) natalia puede pasar desapercibida entre poblaciones de la especie más conspicua, $S(T$.) caliendrum. Discutimos las razones por las que la especie ha pasado desapercibida hasta ahora y los factores que pueden poner en riesgo el mantenimiento de sus poblaciones.

Palabras clave: Sciobia natalia; S. caliendrum; Coexistencia; Distribución europea; Oscilograma; Sonograma.

Recibido/Received: 22/01/2016; Aceptado/Accepted: 29/04/2016; Publicado en línea/Published online: 21/06/2016

Cómo citar este artículo/Citation: P. J. Cordero, P. Cordero \& J. Ortego. 2016. New field data for old museum specimens: A peculiar cricket (Grylloidea, Orthoptera) from SW Spain. Grael/sia, 72(1): e045. http://dx.doi.org/10.3989/graellsia.2016. v72.160

Copyright: (c) 2016 SAM y CSIC. Salvo indicación contraria, todos los contenidos de la edición electrónica de Grael/sia se distribuyen bajo licencia de uso y distribución Creative Commons Attribution License (CC BY) Spain 3.0. 


\section{Introduction}

The South Western Mediterranean is an extraordinary area of diversification of plants and animals with confluence of species or populations with similar habitats on both sides of the Ibero-Maghrebian region. The connexion of both continents in Late Miocene (Messinian stage: 7,2-5,3 MYa) increased dispersion and the diversification and vicariance phenomena of the biota in a complex scenario while climate changes also multiplied ecological successions (Blondel \& Aronson, 1999) and biodiversity (Sanmartín, 2003; Hidalgo-Galiana \& Ribera, 2011). This area forms part of one of the main hot spots of biodiversity of the planet (Myers et al., 2000). The Mediterranean biomes are among the most threatened regions in the world and predictions point to consider the Western Mediterranean as especially vulnerable to biodiversity loss due to drastic changes in human land use and global climate change (Giorgi \& Lionello, 2008; Klausmeyer \& Shaw, 2009).

Among the extraordinary biodiversity of this region, a good example of North African influence in SW Europe is the presence of singular cricket species of the genus Sciobia Burmeister, 1838. This genus constitutes a peculiar group of cricket taxa that originated and radiated from North of Africa, some of which colonised SW Europe. There are 37 Sciobia species described to date (Eades et al., 2016) four of which occur in the Iberian Peninsula (see reviews in Gorochov \& Llorente, 2001; Barranco \& AguirreSegura, 2013). Two species of Sciobia, subgenus Thilptoblemus, inhabit a relatively small piece of land in Europe, in the SW of the Iberian Peninsula. These two species are easily recognized by sight and morphology (i.e. Barranco \& Aguirre-Segura, 2013). The least known European species is Sciobia (Thliptoblemus) barbara Saussure, 1877, now Sciobia (Thliptoblemus) natalia Gorochov, 1985. It is common in Morocco (see review in Chopard, 1943), however, we know virtually nothing about its biology and current European distribution. In fact, the only report to date for Europe (SW Spain) comes from the naturalist M.M. Escalera (1867-1949). He collected one male and one female from Algeciras (Cádiz, province) and donated the specimens to the Museum of Entomology of Madrid (now Museo Nacional de Ciencias Naturales, MNCN). Up to now, all bibliographic literature mentioning the species in Europe (Spain) have Escalera's specimens from Algeciras as the only reference, either as $S$. (T.) barbara (Bolívar, 1925; Bolívar, 1927; Harz, 1969 ) or as S. (T.) natalia (Gorochov \& Llorente, 2001; Barranco \& Aguirre-Segura, 2013). Although, specimen labels have no date of capture, we can estimate roughly the date of Escalera donation occurring between 1914 and 1925. Bolívar (1914) (216p.) did not mention S. (T.) barbara for Spain in his "Dermaptera and Orthopterans of Morocco" which he did for other Moroccan species also present in Spain. However, he mentioned it in his paper on "Contribution to the knowledge of Sciobiae" (Bolívar, 1925) (431p.).

In this paper, we report the presence of $S$. (T.) natalia for Cádiz province and bring information useful for a better understanding of the distribution and biology of the European meta-population of this intriguing species. These data are crucial for its better conservation. To attain this, we performed several field campaigns in Cádiz and surrounding provinces in search of the species and collected information on its distribution, adding notes on its habitats, phenology and behaviour. We also include comparative analyses of the songs of $S$. (T.) natalia and its co-distributed species, $S$. (T.) caliendrum

\section{Material and methods}

During the course of our research projects on fragmentation of small populations of orthopterans, we followed methods used in previous works emphasizing on field collecting data to track rare species of crickets (Cordero et al., 2007; Cordero \& Llorente, 2008). We prospected potential areas in Cádiz and surrounding provinces during different seasons and years, searching for crickets on the ground, under stones, or by detecting their specific song in the field. Field campaigns took place several days in July 2006, August and October 2012; May and June 2014, and May 2015. We only found the species on May and June. Whe hearing Sciobiae species, we used car transects in rural pathways and secondary roads to detect singing plots along hedgerows and edges of open fields on May $(2014,2015)$ and June (2014). Once detected a Sciobia (T.) singing plot, we examined the area in search of the species, whenever conditions were feasible, to increase the prospected territory. We did not attempt to obtain the full current distribution of Sciobia (T.) natalia, but to reveal its current presence in the study area at as many plots as possible. We analysed male songs of Sciobia (T.) natalia and Sciobia (T.) caliendrum in the lab. Recording was under identical conditions for both species, at $21{ }^{\circ} \mathrm{C}$ temperature and in the same hour and day in order to compare oscilograms and sonograms. We used a digital audio recorder Tascam HD-P2, with a K6-M66 Sennheiser microphone and followed the methods described elsewhere (Cordero et al., 2009). We also captured some females to obtain data on breeding under lab conditions. We maintained one female alive in 2014 and 2 in 2015, at room temperature and natural light regime with limited sun exposure to prevent excess of temperature. We kept individuals in plastic boxes for domestic pets with a $2-3 \mathrm{~cm}$ depth of soil mix containing $75 \%$ 
of commercial peat for flowering plants and 25\% of sand, or just with soil directly from the area of capture (Almodovar reservoir). We maintained individuals alive in the lab, recording dates of hatching of nymphs and adult deaths.

\section{Results}

\section{CAPTURE POINTS, GPS DATA, DATES AND SPECIMENS}

Specimens collected are similar to those of Escalera (Algeciras) (Fig. 1a, b) although the largest out of four males presents the facial protuberance that Gorochov \& Llorente (2001) mentioned for $S$. (T.) natalia from Morocco. The study of the taxonomic status of this population will be published somewhere else. We list below plots with detected presence of $S$. (T.) natalia Data points are represented in Fig. 2

(1) $36^{\circ} 9^{\prime} 32.07^{\prime \prime} \mathrm{N}, 5^{\circ} 38^{\prime} 20.87^{\prime \prime} \mathrm{O}$ (UTM: 30S 262594, 4004801). May-31 ${ }^{\text {st }}-2014$; May-25 $5^{\text {th }}-2015$. Almodovar's Reservoir, Facinas, Tarifa (Cádiz province, Spain). $2 \lesssim \widehat{\jmath}$, $2 \uparrow q$ and $1 q$ respectively.

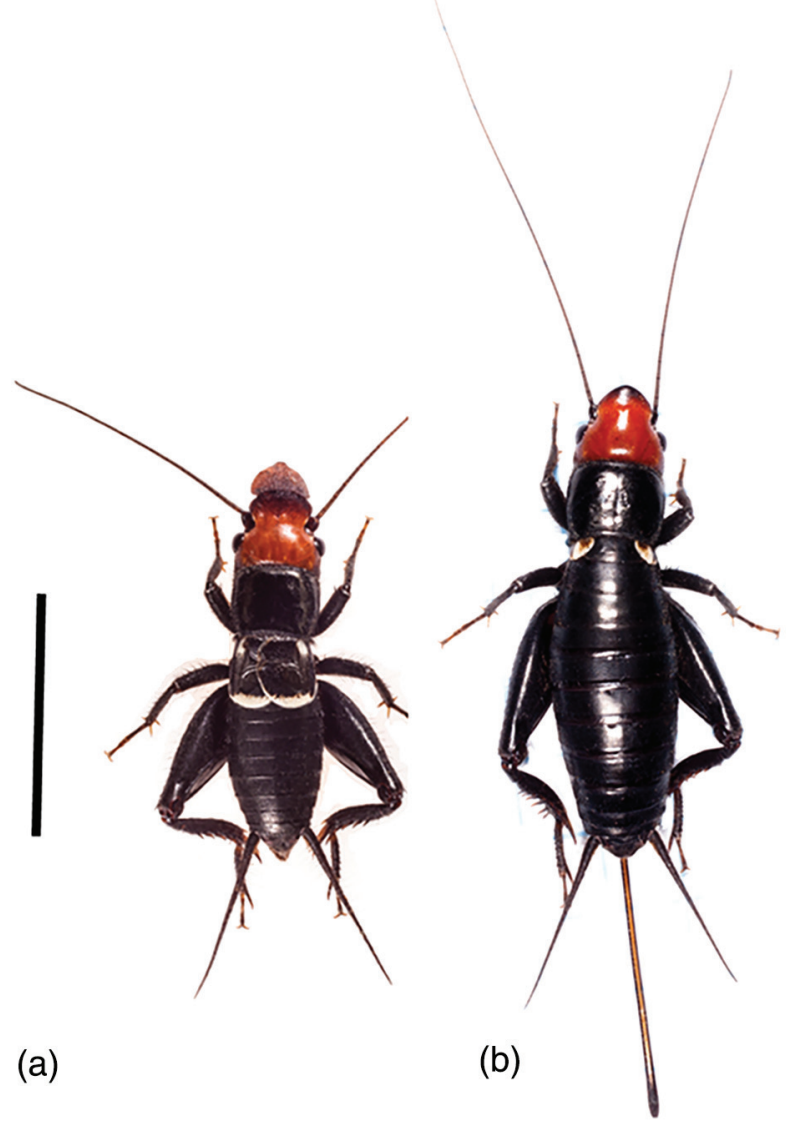

Fig. 1.- Adult male (a) and female (b) Sciobia (T.) natalia from Cádiz province. Scale, $1 \mathrm{~cm}$. Photograph PJC.

Fig. 1.- Adultos macho (a) y hembra (b) de Sciobia (T.) natalia de la provincia de Cádiz. Escala, $1 \mathrm{~cm}$. Fotografía PJC.
(2) $36^{\circ} 21^{\prime} 56.99^{\prime \prime} \mathrm{N}, 5^{\circ} 44^{\prime} 14.32^{\prime \prime} \mathrm{O}$ (UTM: 30S 254409 , 4028006). May-26 $6^{\text {th }}-2015$. Barbate's Reservoir, Benalup-

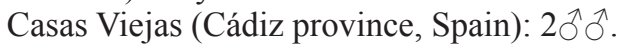

(3) $36^{\circ} 10^{\prime} 51.86^{\prime \prime} \mathrm{N}, 5^{\circ} 48^{\prime} 20.38^{\prime \prime} \mathrm{O}$ (UTM: 30S 247681, 4007681). May-31 1 st 2014 . Sides of the A-2227 road (Zahara de los Atunes- E5 road), Tarifa (Cádiz province, Spain): $2 \partial^{\widehat{\partial}}$ and 19 .

(4) $36^{\circ} 32^{\prime} 41.9^{\prime \prime} \mathrm{N}, 05^{\circ} 46^{\prime} 27.5^{\prime \prime} \mathrm{O}$ (UTM: $30 \mathrm{~S} 251661$ 4047978). June-14 $4^{\text {th }}-2014$. Road hedgerows of the CA-5200, close to Ballesteros stream, Alcalá de los Gazules (Cádiz province, Spain): Sight without capture.

\section{HABITAT, ECOLOGY AND BEHAVIOUR OBSERVATIONS}

The species is local and occasionally abundant in open pasture meadows and road or pathways hedgerows during the maximum vegetative growth of herbaceous plants in May and June (Fig. 3). Adults are very active during the day, singing in choruses and moving around in a similar way that the codistributed S. (T.) caliendrum (Fischer, 1853) does, probably coinciding with courtship period. Sciobia (T.) natalia inhabits clay and loamy soils that crack when dried, allowing abundant underground refuges, although they also occupy temporary refuges under stones. They occur in non-cultivated fields and meadows, particularly in the proximities of water reservoirs, in open land of cattle states with several grasses and other herbaceous plants like Daucus, Cynara, Malva or the predominant Scolymus hispanicus scattered with small patches of bare ground i.e., typical cattle grazing land. We found it at the edges of the fields, and open hedgerows probably because of minor influence of cattle and more dense herbaceous vegetation. In three of the four localities mentioned (points 1,2 , and 4), $S$. (T.) natalia coexisted with the more abundant, widespread and conspicuous $S$. (T.) caliendrum, a species that presents a relatively wider distribution and ecological spectrum, occupying more diverse and drier plots, including those with scarce vegetation in mountainous areas of Sierra de Grazalema (data for this species not shown). The highest concentration of $S$. (T.) natalia occurred in point 3, on May $31^{\text {st }}, 2014$. Density was around 0.25 individuals per square meter in a humid hedgerow plot $(225 \times 15$ $\mathrm{m})$ of bare ground and dense tall grasses (Avena, Brachypodium, Polypogon) influenced by the "Pozo del Gallego" stream that crosses it in the lower side of the plot. This is the only plot in which $S$. (T.) caliendrum did not co-occur with $S$. (T.) natalia. On June $14^{\text {th }} 2014$, vegetation at this point was drier and we did not detect any individual by direct recording. On May $26^{\text {th }} 2015$, horses grazed out, trampled the grass and eutrophicated the ground in this point; humidity was also lower than in previous year. We could not record any individual neither. 


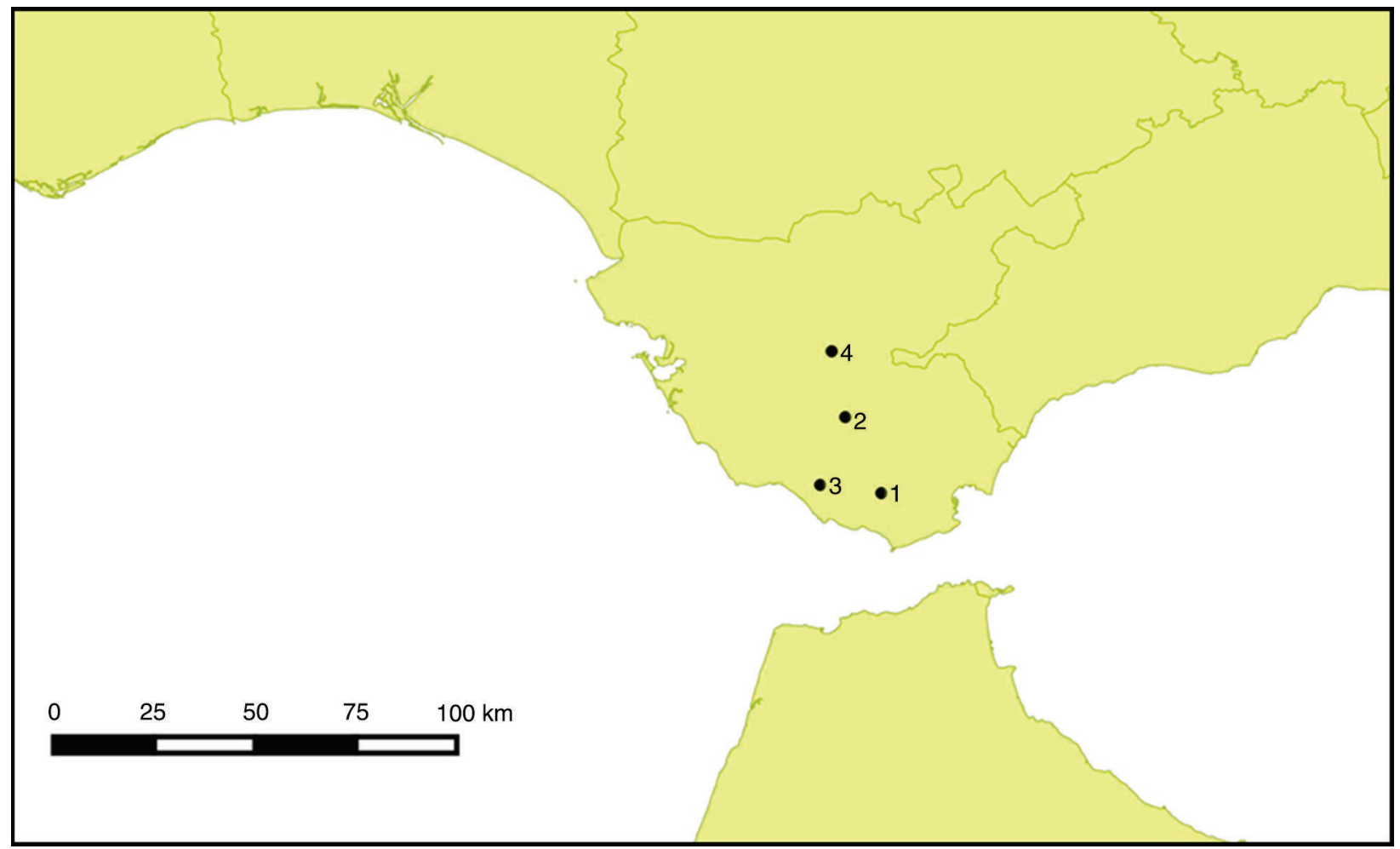

Fig. 2.- Map of Sciobia (T.) natalia recordings made with QGis 2.10.1 Pisa. Numbers correspond to the four points described on the text.

Fig. 2.- Mapa de los registros de Sciobia (T.) natalia hecho con QGis 2.10.1 Pisa. Los números corresponden a los cuatro puntos descritos en el texto.
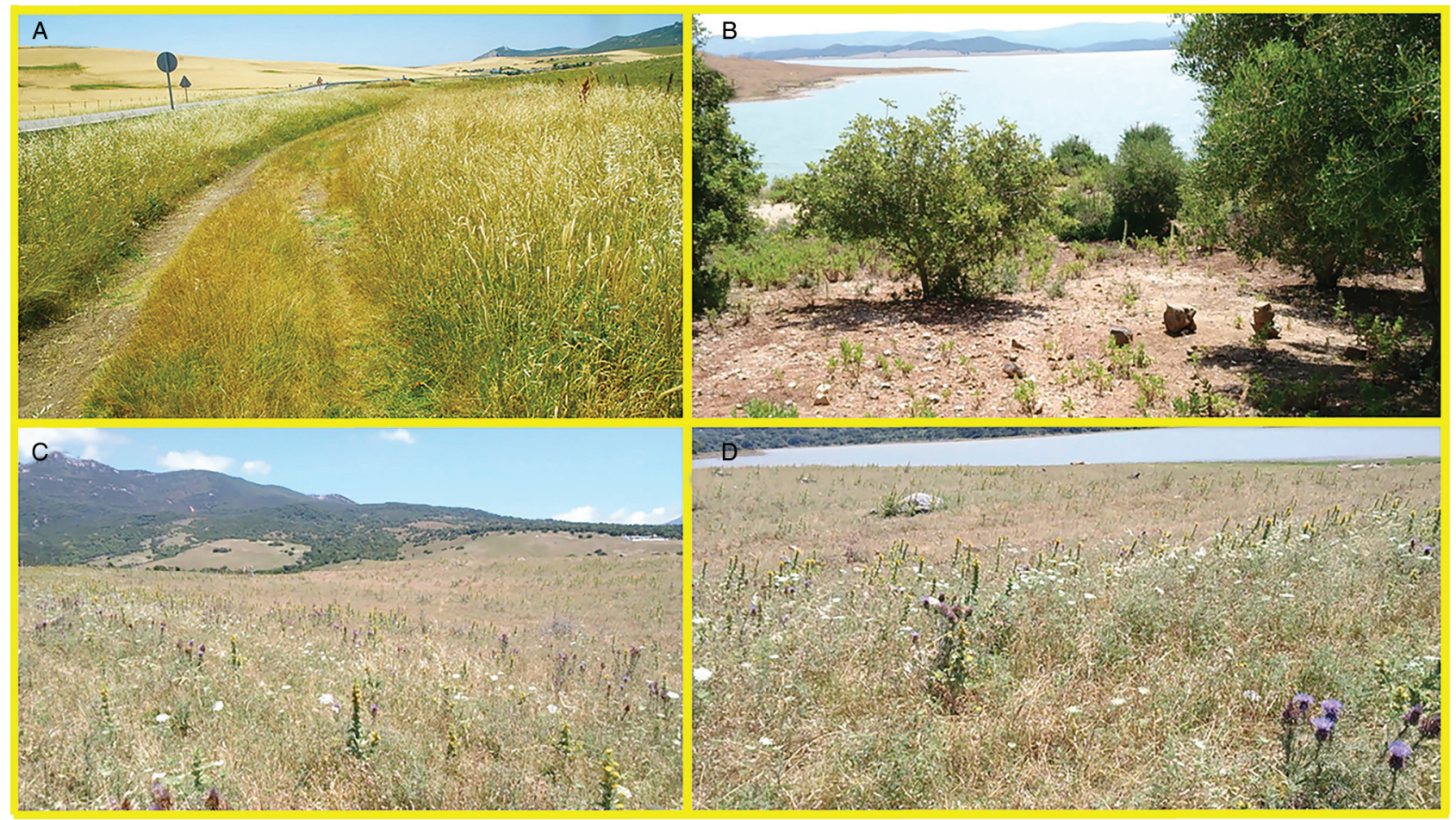

Fig. 3.- Habitats with presence of Sciobia (T.) natalia (A: point 3); Sciobia (T) caliendrum (B: surroundings of point 2) and both species (C, D: point 1). Points as in Fig. 2. Photograph PJC.

Fig. 3.- Hábitats con presencia de Sciobia (T.) natalia (A: punto 3); Sciobia (T) caliendrum (B: lugar próximo al punto 2) y de ambas especies (C, D: punto 1). Puntos como en la Fig. 2. Fotografía PJC. 
In Almodovar and Barbate reservoirs (points 1 and 2), both species coexisted although $S$. (T.) natalia seemed to be more frequent than $S$. (T.) caliendrum in Almodovar (a plot of dense herbaceous vegetation, on May 2014). In Barbate's shores, we only found $S$. (T.) natalia in small plots of dense open herbaceous vegetation whereas $S$. (T.) caliendrum was extraordinary abundant (song choruses and direct observations) in neighbour large plots with sparse scrubs, trees and stony ground with more proportion of bare ground. For both reservoirs, May 2014 was better than May 2015 and June 2014 was negative for direct observations of $S$. (T.) natalia, but nor for $S$. (T.) caliendrum.

In point $4, S$. (T.) caliendrum was predominant all around both in May 2014 and 2015, but we identified only one specimen of $S$. (T.) natalia on June $14^{\text {th }} 2014$. We recorded one male close to the edge of a state with abandoned and sparse olive trees with some scrubs and high herbaceous vegetation, mainly Scolymus hispanicus. The presence of sparse trees, high scrubs and herbaceous vegetation together with certain humidity due to the proximity of Ballesteros stream probably facilitated the presence of $S$. (T.) natalia.

Hatching in the lab occurred on some date of first half of July 2014 and on July $2^{\text {nd }}$ and July $9^{\text {th }}$ for the 2015 females. Adults died between mid-June and the end of July whereas nymphs overwintered, those of 2014 becoming adults on May 2015. Nymphs of $S$. (T.) natalia present the darkest colouration compared with the rest of other Iberian Sciobia nymphs species, changing to black jet, particularly on head and pronotum from November-December onwards (Fig 4). The species presents a univoltine reproductive cycle. Nymphs could spend between 8-9 months in subterranean galleries and crevices, so that the type

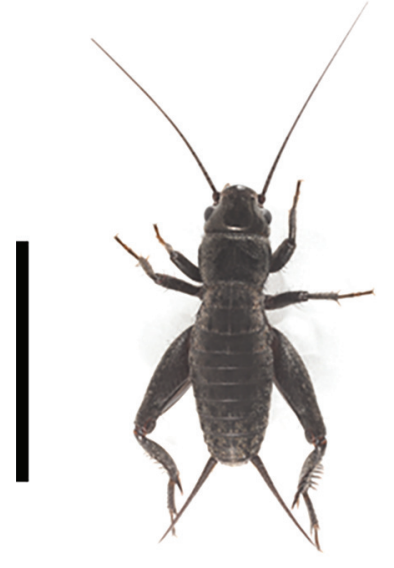

(a)

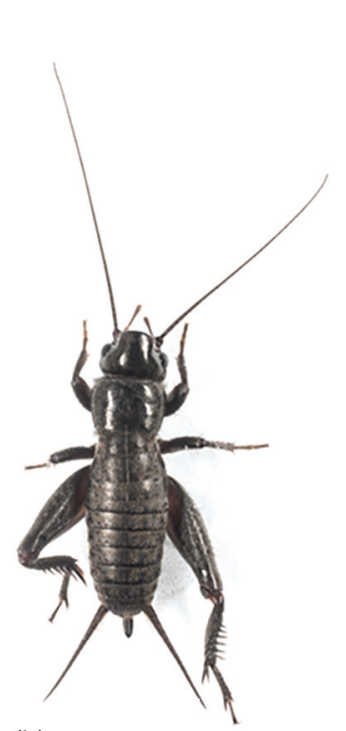

(b)
Fig. 4.- Male (a) and female (b) nymphs of Sciobia (T.) natalia during winter. Scale, $1 \mathrm{~cm}$. Photograph PJC.

Fig. 4.- Ninfas macho (a) y hembra (b) de Sciobia (T.) natalia en invierno. Escala, $1 \mathrm{~cm}$. Fotografía PJC. and structure of the soil may be of great importance for the species. We could not find any nymph under stones in any other prospecting campaigns of July 2006, August 2012 or October 2012. Nymphs eventually could come up to surface by night or in periods of heavy rain as it may occur in other cricket species.

To the human ear, the song uttered by $S$. (T.) natalia can be distinguished from that of $S$. (T.) caliendrum. It is shorter, raspy, less intense and less musical than in $S$. (T.) caliendrum. In Fig. 5, we depict waveforms and spectrograms. Sciobia (T.) caliendrum shows a more continuous singing activity than $S$. (T.) natalia. Chirps are quite different between species. Chirps are $100 \mathrm{~ms}$ in length with an uniform, low amplitude decay of 100-200 ms long (Fig. 5C) and are composed of 6-9 syllables of regular amplitude with the first to third increasing progressively and maintaining this maximum to the end (Fig. 3E). The syllable presents amplitude modulation (Fig. 5G) at 6 and $5 \mathrm{KHz}$ respectively (Fig. 5I) related with a trill-type sound effect. On the contrary, $S$. (T.) natalia chirp is longer (250-350 ms) (Fig. 5D) with an average of 25 syllables per chirp

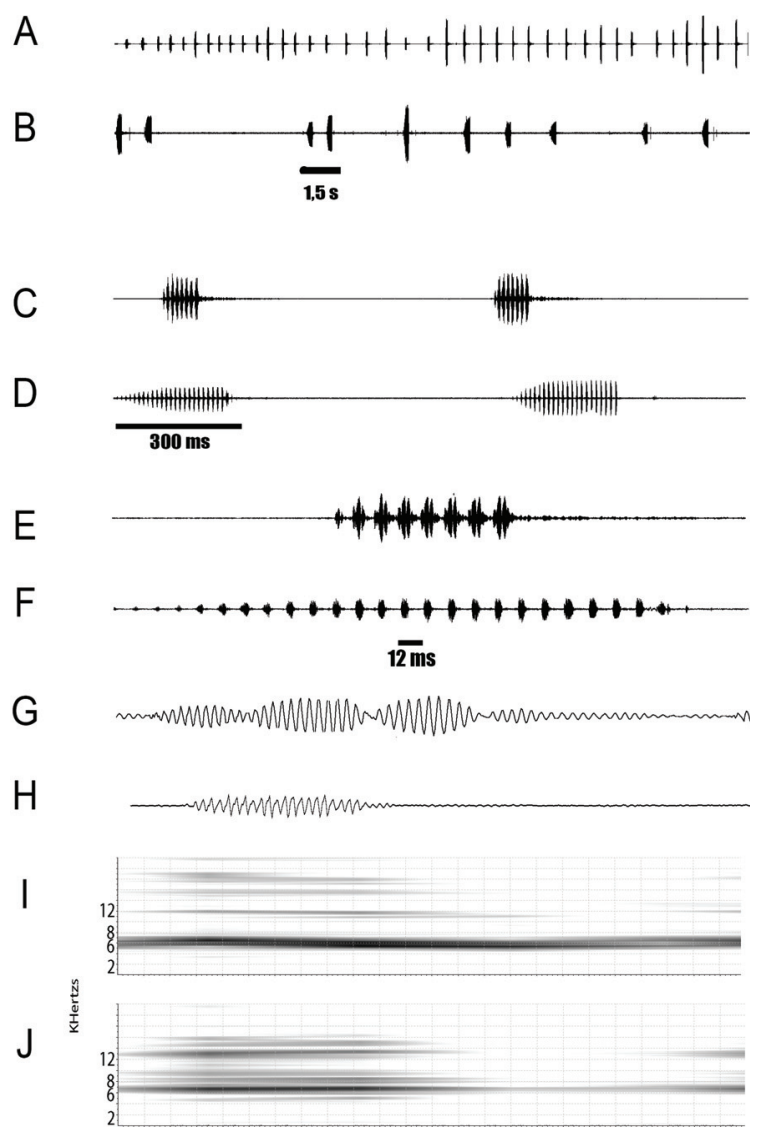

Fig. 5.- Oscilograms $(A-H)$ and spectrograms (I-J) of Sciobia (T) caliendrum (A, C, E, G, I) and Sciobia (T) natalia $(B, D, F, H, J)$. A, B, song of 30 s length; C, D, chirps; E, F, syllables per chirp; $\mathrm{G}, \mathrm{H}$, waveform of single syllable.

Fig. 5.- Oscilogramas (A-H) y espectrogramas (I-J) de Sciobia (T) caliendrum (A, C, E, G, I) y Sciobia (T) natalia (B, D, $F, H, J)$. A, B, Cantos de 30 s de duración; $C, D$, equemas; $E, F$, sílabas por equema; $\mathrm{G}, \mathrm{H}$, forma de onda de sílaba única. 
(range 23-28) and a progressive amplitude with sharp end (Fig. 5F). The syllable presents an only component at $7 \mathrm{Khz}$ (Fig. 5H).

\section{Discussion}

Our observations suggest that $S$. (T.) natalia is not as rare as expected within the open landscape of part of Cádiz province. According to our observations, it prefers more dense vegetation as we did not find it in either drier or bare grounds where $S$. (T.) caliendrum may still be present. However, more intense study is necessary to attain a full picture of habitat variation for $S$. (T.) natalia and its full distribution in SW Spain.

\section{WHY WE HAVE NO RECORDS OF S. (T.) NATALIA SINCE ESCALERA FOUND IT FROM ALGECIRAS?}

Several factors may have contributed to this situation: (1) Factors related with the species specific behaviour and distribution. The distribution range of the species in the Iberian Peninsula, although still probably incomplete, is most likely very small. Further, its behaviour is cryptic, preferring dense herbaceous vegetation where individuals are more difficult to find. The species is probably active and visible only a few weeks in a year, spending most of the time in underground galleries and deep soil crevices, particularly in nymphal stages. According to our observations, it is probable that yearly climate fluctuations change population sizes or modify conspicuous behaviour, and thus the numbers of individuals detected in the field may change enormously yearto-year. (2) According to our field observations, we believe that an important reason for $S$. (T.) natalia going unnoticed is the coexistence in mosaic areas of appropriate microhabitats with $S$. (T.) caliendrum, a more conspicuous relative species. In the appropriate dates, $S$. (T.) caliendrum is extraordinary noisy and visible in areas where $S$. (T.) natalia can also be present. Sciobia (T.) caliendrum may be present at high densities in certain plots where choruses are heard everywhere with a louder and ubiquitous song, masking the presence of $S$. (T.) natalia, even if recognized by ear. Under the same situation, most of the visual contacts are for $S$. (T.) caliendrum that is easier to find in plots with bare ground or with short or sparse vegetation. A shallow evaluation probably result in $S$. natalia going unnoticed, which may be the case in some of the many areas in which we found $S$. (T.) caliendrum. (3) The lack of researchers devoted to studies of classical taxonomy, species discovery, descriptive work on faunistics of arthropods and prone to combine museum with field research. This is a serious problem for biodiversity assessment and respond to the low promotion value and poor funding of these kind of studies, particularly neglected for many decades (e.g. Wheeler et al., 2004).

\section{CONSERVATION CONCERNS}

The crowd courtship of Sciobia (T) crickets, singing and moving in large numbers in certain plots of the Cádiz province, is an entomological phenomenon worth preserving for Europe. The limited extension of the distribution area of $S$. (T.) natalia and its dependence on anthropic habitats submitted to changes in land use may enhance hazardous threats for populations in small geographic areas. Unexpected changes in agricultural policy like over-increasing cattle density (as in other Spanish Regions); changes of land use for agriculture, a widespread misuse of pesticides or the introduction of harmful alien species for Sciobiae, are human-dependent factors that should be avoided. Stochastic factors like long and severe droughts or important flooding events may also influence populations negatively in a region particularly vulnerable to climate oscillations (e.g. Giorgi \& Lionello, 2008). Conservation measures should include the knowledge of the existence of the species, the recognition of its habitats and the maintenance of traditional land uses.

\section{Acknowledgments}

We thank Raquel Méndez and José M. Aparicio for their company and help in different field campaigns. We also acknowledge the unconditional help of Vicenta Llorente and the help with collections of curator Mercedes Paris of the MNCN. I thank Laure Desutter-Grandcolas for her positive comments on this ms and to María José González for map building. This study was supported by different grants: POII10-0197-0167; PEII11-2014-023-P cofinanced by the Junta de Comunidades de Castilla-La Mancha (JCCM) and FEDER funds, and also CGL2011-25053 co-financed by the Dirección General de Investigación y Gestión del Plan Nacional I+D+i (MICINN) and FEDER funds. The Dirección General del Medio Natural, Consejería de Medio Ambiente y Ordenación del Territorio of the Junta de Andalucía provided us the corresponding capture authorisations. JO was supported by a Ramón y Cajal fellowship (RYC-2013-12501) and a research contract funded by Severo Ochoa Program (SEV-2012-0262).

\section{References}

Barranco, P. \& Aguirre-Segura, A., 2013. Aportaciones al género Sciobia Burmeister 1838, en la Península Ibérica (Orthoptera, Gryllidae). Boletín de la Sociedad Entomológica Aragonesa (SEA), 52: 165-172.

Bolívar, I., 1914. Dermápteros y Ortópteros de Marruecos. Memorias de la Real Sociedad Española de Historia Natural, 8: 157-293.

Bolívar, I., 1925. Orthoptera Palearctica Critica I. Contribution a la connaissance des Sciobiae (Grill.) Eos, 1: 375-442.

Bolívar, I., 1927. Datos complementarios sobre los Ortópteros de la Península Ibérica. II. Gríllidos. Boletín de la Real Sociedad Española de Historia Natural, 27(1): 96-110.

Blondel, J. \& Aronson, J., 1999. Biology and Wildlife of the Mediterranean Region. Oxford University Press. Oxford. 328 pp. 
Chopard, L., 1943. Faune de l'Empire Française, I. Orthoptéroïdes de l'Afrique du Nord. Larose. París. $450 \mathrm{pp}$.

Cordero, P. J. \& Llorente, V., 2008., The "silver-bell cricket" (Orthoptera, Gryllidae), a forgotten and overlooked cricket submitted to a high risk of extinction in Western Europe. Graellsia, 64(2): 171-180. http://dx.doi.org/10.3989/ graellsia.2008.v64.i2.30

Cordero, P. J., Llorente, V. \& Aparicio, J. M., 2007. A new cricket (Orthoptera, Gryllidae) for Castilla-La Mancha and the Iberian Peninsula. Graellsia, 63(2): 305-313. http://dx.doi.org/10.3989/graellsia.2007.v63.i2.97

Cordero, P. J., Llorente, V., Cordero, P. \& Ortego, J., 2009. Recognizing taxonomic units in the field- The case of the crickets Oecanthus dulcisonans Gorochov 1993, and O. pellucens (Scopoli, 1763) (Orthoptera: Gryllidae): implications for their distribution and conservation in Southern Europe. Zootaxa, 2284: 63-68.

Eades, D. C., Otte, D., Cigliano, M. M. \& Braun, H., Orthoptera Species File. Version 5.0/5.0. http://Orthoptera. SpeciesFile.org. [Accessed 01-08-2016].

Giorgi, F. \& Lionello, P., 2008. Climate change projections for the Mediterranean region. Global and Planetary Change, 63: 90-104. http://dx.doi.org/10.1016/j. gloplacha.2007.09.005

Gorochov, A. V., 1985. [Three new species of the genus Sciobia (Orthoptera, Gryllidae) from North Africa.]. Vestnik Zoologii, 3: 3-6. (En ruso).
Gorochov, A. V. \& Llorente, V., 2001. Estudio taxonómico preliminar de los Grylloidea de España (Insecta, Orthoptera). Graellsia, 57(2): 95-139. http://dx.doi. org/10.3989/graellsia.2001.v57.i2.281

Harz, K., 1969. Die Orthopteren Europas. I. Séries Entomologica, 5. W. Junk. The Hague. 749 pp.

Hidalgo-Galiana, A. \& Ribera, I., 2011. Late Miocene diversification of the genus Hydrochus (Coleoptera, Hydrochidae) in the west Mediterranean area. Molecular Phylogenetics and Evolution, 59: 377-385. http://dx.doi. org/10.1016/j.ympev.2011.01.018

Klausmeyer, K. \& Shaw, R., 2009. Climate change, habitat loss, protected areas and the climate adaptation potential of species in Mediterranean ecosystems worldwide. PLoS ONE, 4(7): e6392. http://dx.doi.org/10.1371/journal. pone.0006392

Myers, N., Mittermeier, R. A., Mittermeier, C. G., Fonseca, G. A. B. \& Kent, J., 2000. Biodiversity hotspots for conservation priorities. Nature, 403: 853-858. http://dx.doi. org/10.1038/35002501

Sanmartín, I., 2003. Dispersal vs. vicariance in the Mediterranean: historical biogeography of the Palearctic Pachydeminae (Coleoptera, Scarabaeoidea). Journal of Biogeography, 30: 1883-1897. http://dx.doi.org/10.1046/ j.0305-0270.2003.00982.x

Wheeler, Q.D., Raven, P.H. \& Wilson, E.O., 2004. Taxonomy impediment or expedient? Science, 303 (5656): 285. http://dx.doi.org/10.1126/science.303.5656.285 